\title{
Effect of Female Camel Urine on Different Testosterone Levels in Adult Male Rats
}

\author{
Khogali M.E. Salwa ${ }^{1}$, Abd Alla M.A. Dalia ${ }^{2}$, Elhassan AM ${ }^{3}$, Ishraga G. Ibrahim ${ }^{1}$, \\ Esra M. Musa ${ }^{1}$, Samia H. Abdarahman ${ }^{1}$ \\ ${ }^{1}$ Central Veterinary Research Laboratories. Soba, Khartoum, Sudan \\ ${ }^{2}$ University Of Khartoum, Faculty of Veterinary Medicine, Department of Biochemistry \\ ${ }^{3}$ AlribatUniversity, Faculty of Pharmacy, Department of Pharmacognasy, Sudan
}

Geliş Tarihi / Received: 08.12.2014, Kabul Tarihi / Accepted: 09.07.2015

\begin{abstract}
Our objectives were to investigate the effect of female camel urine on abnormal hormonal levels in male rats and to evaluate total protein, globulin, albumin and body weight gain according to administration of female camel urine. Twenty four adult Wistar albino rats were divided into four groups, normal testosterone control, treated control and high and low serum testosterone groups which produced by injection of testosterone Enanthate and Lead Acetate respectively twice a week for 21 days. All groups except the control group (normal) were orally dosed female camel urine ( $2 \mathrm{ml} /$ 100 gram body weight) for another 21 days. Female camel urine regulated the high and low testosterone level to their normal serum level. Testosterone level was significantly increased $(\mathrm{P}<0.01)$ in group three after seven days of female camel urine administration. The same time no change was observed on normal testosterone level group. In the 3 th week all treated groups showed significant $(\mathrm{P}<0.01)$ increase in the testosterone level compared to the previous week. Total protein, globulin and albumin were significantly $(\mathrm{P}<0.05)$ elevated before and after female camel urine treatment.
\end{abstract}

Key words: Camel urine, rat, testosterone

\section{Dişi Deve İdrarının Erişkin Erkek Ratlarda Farklı Testosteron Seviyelerine Etkisi}

\begin{abstract}
Özet: Bu çalışmada dişi deve idrarının erkek ratlarda anormal hormon seviyelerine etkisi ile total protein, globulin, albümin ve canlı ağırlık artışı değerlerindeki değişimin araştırılması amaçlandı. Yirmi dört erişkin Wistar albino rat; normal testosteron kontrol, tedavi edilmiş kontrol, yüksek serum testosteron ve düşük serum testosteron olmak üzere dört gruba ayrıldı. Düşük ve yüksek testosteron seviyeleri 21 gün boyunca haftada iki kez testosteron enantat ve kurşun asetat enjeksiyonu ile sağland. Enjeksiyonlar ile başlangıç seviyelerine ve kontrol grubuna göre istatistiksel olarak önemli testosteron seviyeleri elde edildi $(\mathrm{P}<0,01)$. Kontrol grubu hariç tüm gruplara 21 gün boyunca oral olarak dişi deve idrarı verildi ( $2 \mathrm{ml} / 100 \mathrm{~g}$ vücut ağırlığı). Dişi deve idrarı düşük ve yüksek testosteron seviyelerine sahip gruplarda testosteron seviyelerini normal serum seviyelerine düşürürken, normal serum seviyesine sahip tedavi edilmiş grupta idrar uygulamasından 7 gün sonra testosteron seviyesinde herhangi bir değişikliğe yol açmadı. Tedavi edilmiş tüm gruplarda üçüncü haftada bir önceki haftaya kıyasla testosteron seviyelerinde istatistiksel olarak önemli artışlar şekillendi $(\mathrm{P}<0,01)$. Total protein, globulin ve albümin seviyeleri idrar uygulamasından önce ve sonra yükseldi $(\mathrm{P}<0,05)$.
\end{abstract}

Anahtar kelimeler: Deve idrarı, rat, testosteron

\section{Introduction}

Urine of one humped camel (Camelus Dromedaries) is medically used for centuries in different parts of Arab countries. It has been shown throughout the history of medical science till today that urine has a profound medical uses for allergies, psoriasis, burns, internal disorders, tuberculosis, fertility, alopecia and cancer $[12,8,13]$. Camel urine can influence the hormonal changes that lead to hair losses.

Testosterone is a more potent androgen that results in miniaturization of hair follicle and changes the cyclic phase of hair growth cycle [17]. Hormonal problems are one of the causes of hair loss [14]. Testosterone is the major hormone that affect fertility in men, it is needed to initiate spermatogenesis at puberty and for maintenance of this process in the adult. Sex hormone levels can cause changes in body composition independently and through mediating factors. Testosterone has anabolic effects which promote protein synthesis and growth of the tissues, growth of muscle mass and strength, increase bone density and strength, stimulation of linear growth and bone maturation. Testosterone 
and 5 alpha dihydrotestosterone (DHT) are responsible for most of the biological androgenic effects. Several studies discussed the effect of natural products, herbs and medicinal plants on Testosterone Hormone Level [2], but research that conducting the effects of camel urine on hormones or protein metabolism are scarce. This study is designed to examine the effect of camel urine on different (TL) together with some parameters related to protein metabolism namely serum total protein, globulins and albumin as well as body weights.

\section{Materials and Methods}

\section{Experimental Animals}

In this study 24 Wistar albino, adult male rats weighing 140 to 200 grams are used. Animals were kept in the Central Veterinary Research Laboratories premises at Soba, Khartoum, Sudan. They were kept under standard condition of temperature $\left(23^{\circ} \mathrm{C}\right)$ and relative humidity (65\%) $12 \mathrm{~h}$ light and $12 \mathrm{~h}$ dark cycle and adequate ventilation, they were provided with balanced diet and water ad libitum.

\section{Experimental Design}

Rats were randomly selected and assigned into four groups. Group one was control for normal testosterone level, group two was control for female camel urine, group three and four represent high and low testosterone levels.

\section{Dosing}

Urine was collected by natural urination or by tashweel technique (2 ml/100Gb.w) high and low Testesterone level were brought by parental injection of Testosterone Enanthate $(1.5 \mathrm{mg})$ and Lead Acetate $(8 \mathrm{mg})$ respectively according to the method described by Brunner et al., [5] and [4].

\section{Blood Samples}

Blood samples were taken once before female camel urine (FCU) treatment and weekly after FCU treatment .The samples were collected in a plain vials, allowed to stand and thereafter centrifuged at 2000 rpm for 10 minutes, serum was then separated and frozen at $20^{\circ} \mathrm{C}$ till analyzed.

\section{Hormonal Assay}

Serum testosterone was measured by enzyme linked immunosorbent assay (ELISA) microwell method described by Rajkowski et al., [15].

\section{Biochemical Analysis}

Total protein and albumin were determined according to Friedman and Young, [7]. Using Biuret reagent kit and Bromocresol green.

Globulin values were calculated by subtracting the values of albumin from the corresponding values of total protein [1].

\section{Statistical Analysis}

Statistical analysis was performed using computer software package statistics (Version 8). It was used to perform analysis of variance (ANOVA), Day and Quinn [6].

\section{Results}

The variation in the effect of female camel urine in the testosterone levels are illustrated in figure 1. Testosterone level was significantly increased $(\mathrm{P}<0.01)$ in group three after seven days of female camel urine administration. The level of Testosterone was somewhat increase in group four, no changes were observed in groups one and two. At day 21 there was an increase in serum testesterone level in all groups treated with FCU compared to the previous weeks.

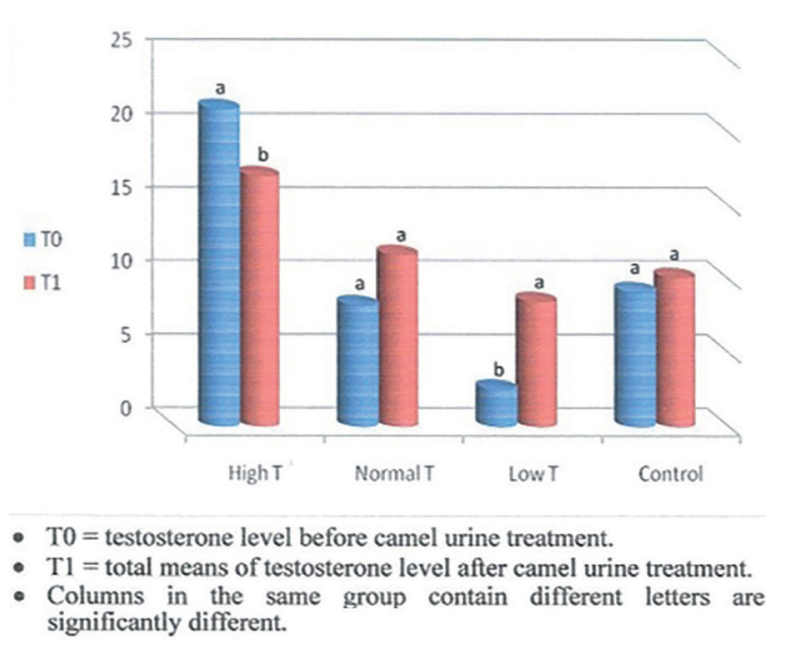

Figure 1. Effect of female camel urine on testosterone level(ng/ml) 
The effect FCU on the total protein under different testosterone levels in the treated rats is shown in figure 2. At day zero high and low testesterone level groups were found to have significantly low $(\mathrm{P}<$ 0.05 ) serum total protein compared to the control group. In all groups after two weeks administration of female camel urine, total protein levels were significantly $(\mathrm{P}<0.01)$ increased and became at the same level in the control group (Figure 2).

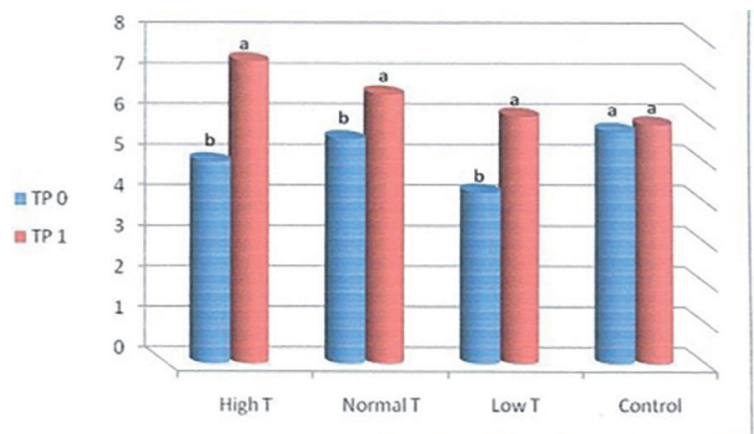

- TP $0=$ Total protein level before camel urine treatment.

- TP $1=$ Total means of total protein level after camel urine treatment.

- Columns in the same group contain different letters are significantly different.

Figure 2. Effect of female camel urine on the rat serum total $\operatorname{protein}(\mathrm{g} / \mathrm{dl})$

Although, serum albumin significantly increased $(p<0.05)$ compared to the previous week in the normal testosterone group after seven days of female camel urine administration, no change was observed in all other treated groups (Figure 3)

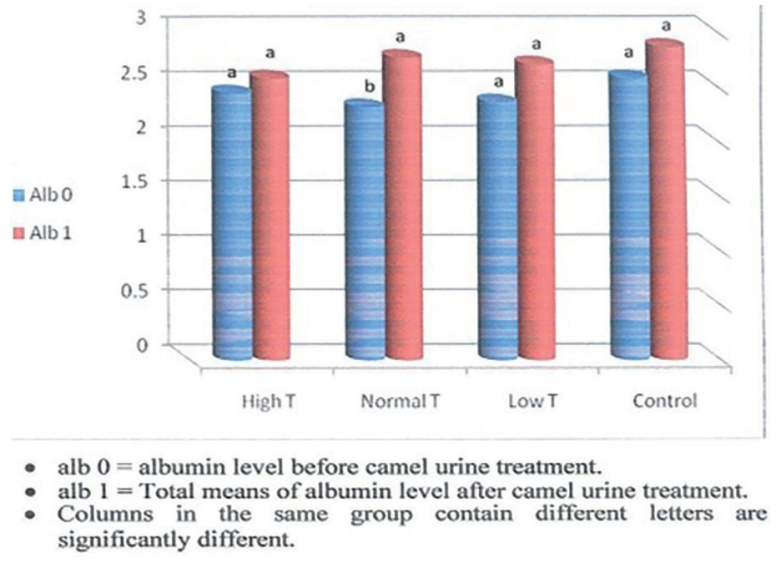

Figure 3. Effect of she-camel urine on the rat serum albumin level $(\mathrm{g} / \mathrm{dl}$.)

Figure (4) represents the influence of FCU on globulin level in all groups. Serum globulin was signifi- cantly $(p<0.01)$ elevated after seven days of FCU treatment .There was significant $(p<0.05)$ increase in the normal testosterone group compared to the previous days .All groups showed an increase in globulin level at day 14 and 21, but high testosterone group was significantly $(p<0,01)$ higher than the controlgroup during all weeks of treatment.

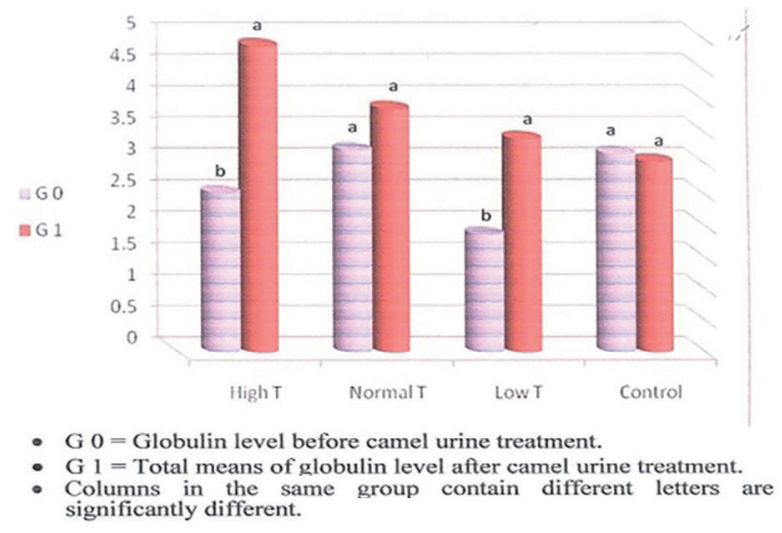

Figure 4. Effect of she-camel urine on the serum globulin level $(\mathrm{g} / \mathrm{dl})$

\section{Discussion and Conclusion}

In the present study, high serum testosterone in male rats showed highly significant $(\mathrm{P}<0.01)$ lower level after 7 days of FCU administration compared to day zero and remained stable for another week. On day 21 the hormonal level was raised to nearly the same level before FCU administration. This may be due to the presence of none sterified fatty acids which can inhibit testosterone synthesis by affecting cholesterol utilization or endogenous concentration [11].This findings were similar to Wayne et al, [20], who found that Oleic acid treatment inhibited testosterone synthesis by inhibiting cholesterol esterase activity. Also Tehming and Shutsung, [18] reported that some unsaturated fatty acids (Linoleic, palmitleic , oleic and myristoleic) are potent inhibitors of 5- $\alpha$ reductaseenyme which convert testosterone into 5- $\alpha$ dihydrotestosterone. High testosterone reduce total protein in this study which in agreement with Mebh et al., [10] findings, also Baron, [3], documented that three factors may lead to a decrease in plasma total protein and albumin concentration, liver damage impaired intake of protein and toxic destruction of the protein . Albumin was slightly affected and this was in agreement with Sharaf et al, [16] and Zaki et al., [21] who studied lead toxicity 
in bulls and marino sheep respectively and disagree with Voet and Voet, (19) who found a significant increase in serum albumin. However, FCU caused highly significant $(\mathrm{P}<0.01)$ elevation on serum total protein and globulin level after 7, 14 and 21days. The increment observed in total protein, globulin and normalization of elevated hormonal levels might be due to the nourishing compounds in camel urine [9].

Oral administration of female camel urine for three weeks resulted in transient lowering on the high testosterone level, gradual increase in the low testosterone level while the group of normal level was not affected by FCU administration. All groups treated by FCU showed significant increase in total protein, globulin and rats body weight. This study concluded that camel urine can rectify and regulate serum testosterone level, increase protein synthesis and support the body immunity.

\section{References}

1. Abdel Fattah S A., El Sanhoury MH., El Medany NM., Abdel Azeem F., (2008). Thyroid activity, some blood constituents, Organs morphology and performance of broiler chicks supplemental Organic acids. Int J Poultry Sci, 7(3), 215222.

2. Arash KD., Fatemeh F., Mohammad N., Amir AK., Chelar CO., Marefat G., Mohammad H., (2009). The effects of ginger on spermatogenesis and sperm parameters of rat. Iranian J Reproductive Med, 7, 7-12 .

3. Baron DN., (1973). Short textbook of chemical pathology ( $3^{\text {rd }}$ edition) English Language and book society (ELBS) Hodder and Stoughton London. pp87.

4. Biswas NM., Ghosh, P., (2004). Effect of Lead on male gonadal activity in Albino Rats, Kathmandu Uni. Med J, 2, 43-46.

5. Brunner M., Schraner EM., Wild P., (1992). Cellular Changes in rat parathyroid provoked by progesterone and testosterone. Cell Tissue Res. 268, 283-286.

6. Day RW., Quinn GP., (1989). Comparison of treatments after analysis of variance in ecology. Ecological Monographs 59, 433-463.
7. Friedman RB., Young DS., (1997). Effect of disease on clinical Laboratory tests. $3^{\text {th }}$ edition, AACC press.

8. Kabariti A., Mazuria S., Elgendi A., (1988). Camel urine a possible anti carcinogenic agent. Arab Gulf J Sci Research Agric Biol Sci, 6, 55-63.

9. Khogali ME., (2005). PhD thesis .Hepatoprotective and Anti parasitic effect of Female Camel Urine in natural infected Calves.(Fashiolasis) University of Khartoum, Faculty of pharmacy, Khartoum, Sudan.

10. Mebh U., Eyong U., Eyong G., Ifere O., Chukwuemeka N., (2005). Theobromine induced seminiferous tubular lesion with elevated serum testosterone levels in male wistarrats . Biochemistry 17 (2), 123-128.

11. Meikle AW., Benson SJ., Lin XH., Boam WD., Stringham JD., (1989). Nonesterified fatty acids modulate esteroidogenesis in mouse Leydig cells. Am J Physiol Endocrinol Metab, 237, 937-942 .

12. Natalie B., (2002). Urine Therapy (drinking urine) J of Brekeley Medicine, www. Ocf.Berkeley.edu.

13. Ohag HM., (1998). Clinical Trials for treatment of ascitis with camel urine. M.Sc. University of Gazera, Sudan.

14. Peter YL., Nicholas A., (2008) Male pattern hair loses.

15. Rajkowski, KM., Cittanova N., Desfosses B., Layle MF., (1977). The conjugation of Testosterone with horseradish peroxidase and a sensitive enzyme assay for the conjugate steroids.

16. Sharaf NE., Zaki SZ., Hind R G.,Nabila EB., Olfat MF., (2008). Some clinicopathological and microbiological studies on Lead toxicity in bull. Amer Eurasain J Agric and Envirom, Sci. 3 (2), 165 -168.

17. Shweta P., Pharm M., Nagendra SC., Dixit VK., (2008). Effect of CuscutsreflexaRoxb on androgen induced alopecia. J of Cosmetic Dermatology, 7, 199- 204.

18. Tehming L., Shutsung L., (1992). Inhibition of $5 \alpha$ reductase by specific unsaturated fatty acids. Biochem J, 285, 557 562 .

19. Voet D., Voet JG., 1990. Biochemistry (1 $1^{\text {st }}$ ed.) New York Wiley sons, p. 1148

20.Wayne M., Jose C, Jitka H, Darrell K (1996).Oliec acid inhibits cholesteryl estrase and testrol utilization for testosterone synthesis in mouse leding cells.J of Metabolism, 45(3) 293-299

20. Zaki MS., Suzan M, Awad I., (2010). Some studies on lead toxicity in marino sheep Journal of American Science, 6(4), 128-131. 